\title{
Thermodynamic and Kinetic Study for the Interaction of Ascorbic Acid with Nickel (II) Ion by Spectrophotometric Methods
}

\author{
Alaa Abd AL-Zahra \\ Department of Chemistry, College of Science, University of Baghdad, Jadiria, Baghdad, Iraq
}

\begin{abstract}
The aim of this paper was study the interaction between ascorbic acid with Nickel (II) by the application of UV-Visible spectroscopic method at four different temperatures $(293,298,303,308) \mathrm{K}$. The change in absorbency improves the complexion between acid and metal ion. The stoichiometry of the interaction was determining by continuous variations methods. The thermodynamic parameters $\left(\Delta G^{\circ}, \Delta H^{\circ}\right.$ and $\left.\Delta S^{\circ}\right)$ and equilibrium constant were calculated at four different temperatures refer to the hydrophobic interaction between metal and acid. The kinetic study for this interaction follows second order equation with rate constant value of $2 \times 10^{-3} \mathrm{M}^{-1} \mathrm{~min}^{-1}$
\end{abstract}

Keywords: Nickel, kinetics, thermodynamic, ascorbic acid.

\section{Introduction}

Ascorbic acid (C6H8O6) is a water- soluble compound. Itis important for biological function, used for synthesis of collagen in tissues, teeth and skin [1-4]. (C6H8O6) molecule has two asymmetric carbon atoms $\mathrm{C}-4$ and $\mathrm{c}-5$. In addition to L-ascorbic acid it has D- iso ascorbic acid, D-ascorbic acid, and L-iso ascorbic acid but they are not activity [5-8]. L ascorbic acid is hetro cyclic lactone ring [9]. Vitamin $\mathrm{c}$ is reducing agent and oxidizes reversibly to dehydro ascorbic acid. It is metabolized in liver involved many amino acid, leading to formation of hydroxyl proline, serotonin, hydroxyl lysine [10]. This vitamin is distributed in nature, special in fresh fruits and vegetables such as spinach. This vitamin increases the absorption of folic acid, calcium and iron [11]. Figure (1) shows the structure of ascorbic acid.

\section{Figure 1: Structural formula of ascorbic acid}

Nickel is metallic compound which is known as transitional metallic in periodic table. nickel (II) is important oxidation state in biochemistry, it is form many complexes. It is considering as essentials elements in the body because it is helping the body to absorb iron, and prevent anemia through building strong skeletal by strengthening bones, it is found in DNA, RNA means found in every cell in human body. Nickel is found in plants (peas, beans), fish and chocolate, it is help in breaking down glucose which help improvised energy for daily requirement's $[12,13]$.
Huned.Y.J. 2004. Study of the interaction between mono ammonium glycyrrhizin ate and bovine serum albumin [14]. HunedY.J. 2005. Stud the interaction between 1hexylcarbamoyl-5-flurouracil and bovine serum albumin [15]. FahadD.F. (2012) study the interaction of an antioxidant with toxic arsenic, and the thermodynamic and kineticparameter were calculated at different temperatures [16]. Al- Khafaji N. R. study the (2014): study effectiveness of poly phenol of Nutritional origin to protection from metal ion [17]. Al-Rufaie E. M. and Hussain. A.K. (2014): Studies the interaction of Vitamin $\mathrm{C}$ and Nickel (II) using polar graphic methods [18].

Al-jubouri M.A. (2015): calculate thermodynamic and kinetic parameter for the binding of heavy metal with drugs [19].

Aim of the project is study the interaction of (vitamin c) and (nickel) by the application of UV-Visible spectroscopic method, the following calculation were done:

a) The stoichiometric ratio of the complexes.

b) The rate constant and the order of interaction.

c) Equilibrium constant and thermodynamic parameters $\left(\Delta \mathrm{H}^{\circ}, \Delta \mathrm{S}^{\circ}, \Delta \mathrm{G}^{\circ}\right)$ for the interaction.

\section{Experimental}

\subsection{Materials}

Pure deionized water was supplied from LV- 08 ultrapure water device. All absorption spectra were taken with the UV-Vis spectrophotometer (Cary Varian) EL04103410, using a quartz cell of $1 \mathrm{~cm}$ path length. The absorbance of acid and metals were calculated in a wavelength (200$600 \mathrm{~nm})$. Nickel nitrate $\mathrm{Ni}(\mathrm{NO} 3) 2.6 \mathrm{H} 2 \mathrm{O}$ was purchased from Analar/ England. L- ascorbic acid C6H8O6 was purchased from HIMEDIA/India.

Nickel stock solution of $\left(10^{-4} \mathrm{M}\right)$ concentration were prepared by dissolve $0.029 \mathrm{gm}$ of Nickel in $100 \mathrm{ml}$ water. Ascorbic 
acid stock solution of $\left(10^{-4} \mathrm{M}\right)$ concentration were prepared by dissolve $0.0176 \mathrm{gm}$ of acid in $100 \mathrm{ml}$ water as solvent.

Stoichiometric analysis: The stoichiometry of acid metals complexation was determined by (Jobs method), by a series of ten solutions have a mole fraction in between (0.1 to 0.9$)$ by mixing different volumes of vitamin and metals stock solutions of a concentration $\left(10^{-4} \mathrm{M}\right)$ for each [20].

\section{Results and Discussion}

\section{Absorption spectroscopy:}

The UV -VIS absorption studies were taken to each ascorbic acid and Nickel and ascorbic acid -Nickel complex. The UV-VIS absorbance showed a shift in $\lambda \max (\lambda \max$ for $\mathrm{Ni}=202 \mathrm{~nm}, \lambda \max$ for acid $=256 \mathrm{~nm}$ and $\lambda \max$ for complex $=261 \mathrm{~nm}$ ) and aching in the absorbance due to complex formation between metal and vitamin, Figure2(a, b,c)show the absorption spectra of acid and metal.

acid + metal $\rightleftharpoons$ acid metal complex

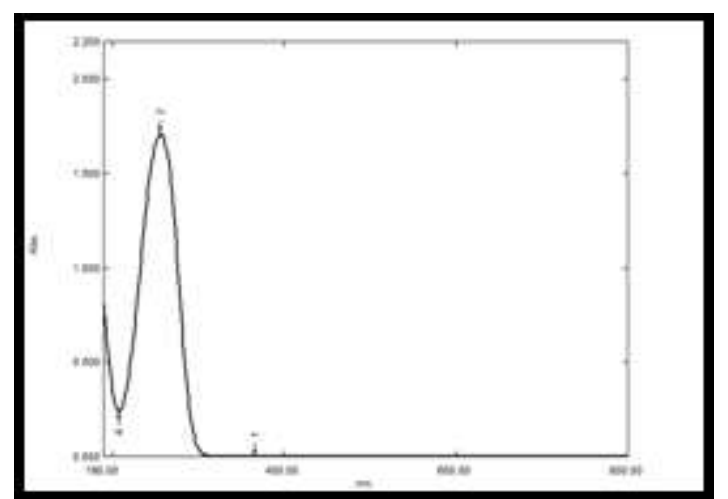

(a)

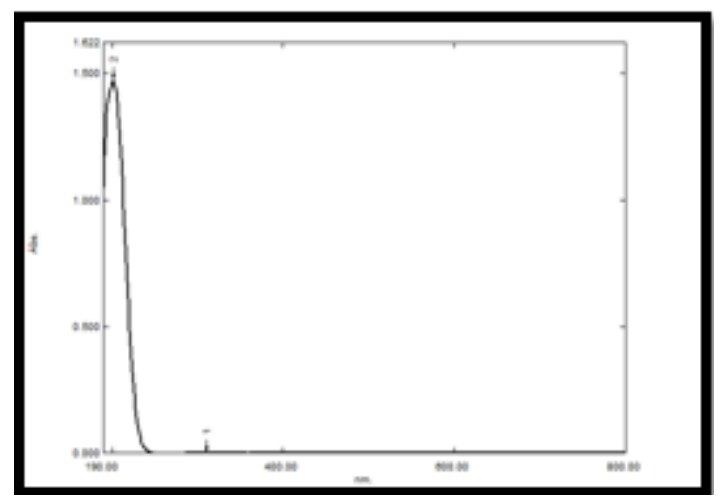

(b)

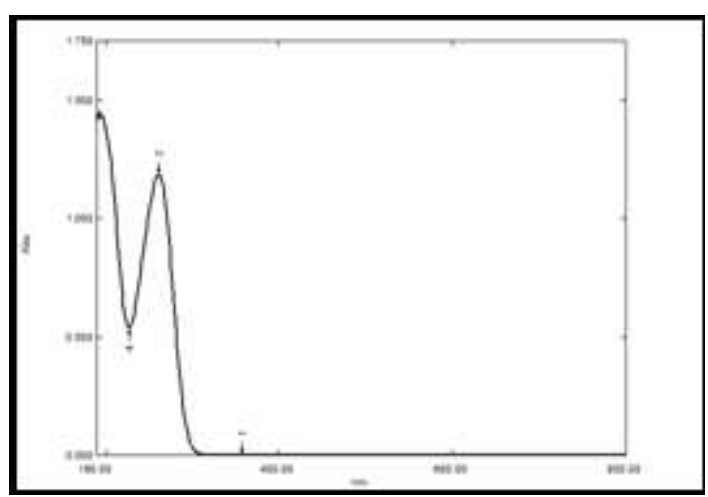

(c)

Figure 2 (a): Absorption spectrum of ascorbic acid in pure deionized water

(b): Absorption spectrum of Nickel in pure deionized water. (c): Absorption spectrum of Ascorbic acid -Nickel complex in pure deionized water.

\section{Stoichiometric analysis}

The continuous variation methods used to determine stoichiometry of the complex of ascorbic acid and Nickel (II) [21]. The coordination number $\mathrm{n}$ could be calculated from the plot of absorbance ofascorbic acid -Nickel complexat $\lambda \max (261 \mathrm{~nm})$ against the mole fraction of Nickel. As it evident from the Figure (3) the Job's plot, indicates that the stoichiometric ratio $n$ of ascorbic acid -nickel at (293)K is (1:1).

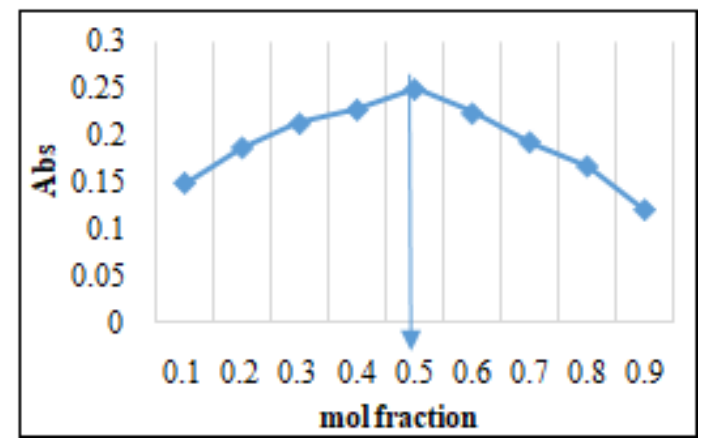

Figure 3: Job's plot for Nickel-ascorbic acid complex

Stability constant (Keq): by continuous variation method, the equilibrium constant can be calculated as show in equation (2) [22, 23]:

$$
K_{\text {eq }}=\frac{[\text { AMncomplex }] e q}{[M]_{\text {oq }}[A]_{\text {eq }}}
$$

$\left[\mathrm{AM}_{\mathrm{n}} \text { complex }\right]_{\mathrm{eq}}$ : concentration of the complex formed between the Nickel and ascorbic acid at equilibrium. $[\mathrm{M}]_{\mathrm{eq}}$ : concentration of the metal at equilibrium.

$[\mathrm{A}]_{\mathrm{eq}}$ : concentration of the acid at equilibrium.

$\left[\mathrm{AM}_{\mathrm{n}}\right.$ complex $_{\mathrm{eq}}=$ Absorbance $_{(\max )} / \varepsilon l \ldots$ (3) $\varepsilon$ : molar absorptivity of the complex $\left(\mathrm{cm}^{-1} \cdot \mathrm{mol}^{-1} . \mathrm{L}\right)$. $l$ : path length $(\mathrm{cm})$.

Absorbance $(\max )=$ the maximum absorbance of the complex

The molar absorptivity of the complex was calculated by recording the absorbance of a various concentration of 1:1complex with their stoichiometric ratio, at different temperatures, according to Beer's law, and plotting the absorbance against concentration which given a straight line 


\section{International Journal of Science and Research (IJSR)}

ISSN (Online): 2319-7064

Index Copernicus Value (2016): 79.57 | Impact Factor (2015): 6.391

with a slope equals to $\varepsilon$ for this complex. This was illustrated inTable (1): [24, 25].

Table 1: Molar absorptivity of complexes at four temperature

\begin{tabular}{|c|c|}
\hline$T(k)$ & $\begin{array}{c}\text { Molar absorptivity } \varepsilon\left(\mathrm{L} . ~_{\mathrm{mol}}^{-1} \mathrm{~cm}^{-1}\right) \text { of } \\
\text { ascorbic acid and Nickel }\end{array}$ \\
\hline 293 & 3660 \\
\hline 298 & 3773 \\
\hline 303 & 4125 \\
\hline 308 & 4276 \\
\hline
\end{tabular}

The equilibrium constants calculated by this method were determined in four different temperatures $(293,298,303,308)$ $\mathrm{K}$ as shown in Table (2)

Table 2: The equilibrium constants of acid -metal complex at different temperatures

\begin{tabular}{|c|c|c|c|}
\hline $\mathrm{T}(\mathrm{k})$ & $\Delta \mathrm{G}^{\circ}\left(\mathrm{J} \cdot \mathrm{mol}^{-1}\right)$ & $\Delta \mathrm{H}^{\circ}\left(\mathrm{J} \cdot \mathrm{mol}^{-1}\right)$ & $\Delta \mathrm{S}^{\circ}\left(\mathrm{J}^{\mathrm{mol}}{ }^{-1} \mathrm{~K}^{-1}\right)$ \\
\hline 293 & -38245.23 & 20618.72 & 200.900 \\
\hline 298 & --39170.41 & 20618.72 & 200.634 \\
\hline 303 & -40155.12 & 20618.72 & 200.573 \\
\hline 308 & -40817.7 & 20618.72 & 199.468 \\
\hline
\end{tabular}

The results of table (2) show that these stability constants changes slightly with the range of temperature used in this work (293-308K). It increases with increase in temperature for (acid -metal) complex. That mean the stability of complex increase with temperature which means the bond between them becomes stronger [26, 27].

Thermodynamic Parameters: The free energy changes $\Delta \mathrm{G}^{0}$, the enthalpy changes $\Delta \mathrm{H}^{0}$ and the entropy changes $\Delta S^{0}$, was calculated at four different temperatures $(293,298,303,308) \mathrm{K}$ for complex.

The enthalpy changes were calculated by substitute the value of the slope of the plot (LnKeqvs.1/T) in the vant Hoff equation (4), the result as shown in Figure (4) and Table (3) [28-30].

$$
\ln K e q=-\Delta H^{0} / R T+\Delta S^{0} / R
$$

Slope $=-\Delta H^{0} / R$

$\mathrm{R}=$ gas constant.

The change in Gibbs free energy can be determined from equation (5), the relation between $K_{e q}$ and $\Delta G^{o}$ and the entropy changes from equation (6).

$$
\begin{aligned}
& \Delta G^{\circ}=-R T \operatorname{Ln} K e q \\
& \Delta G^{\circ}=\Delta H^{\circ}-T \Delta S^{\circ}
\end{aligned}
$$

Table 3: Thermodynamic parameters for ascorbic AcidNickel in deionized water at different temperature \begin{tabular}{|l|l|}
\hline Temp. (K) & $\mathrm{K} \mathrm{eq}\left(\mathrm{L} \cdot \mathrm{mol}^{-1}\right)$ of ascorbic acid and Nickel in water \\
\hline
\end{tabular}

\begin{tabular}{|l|l|}
\hline 293 & $6.67 \times 10^{5}$ \\
\hline 298 & $7.38 \times 10^{5}$ \\
\hline 303 & $8.38 \times 10^{5}$ \\
\hline 308 & $10.9 \times 10^{5}$ \\
\hline
\end{tabular}

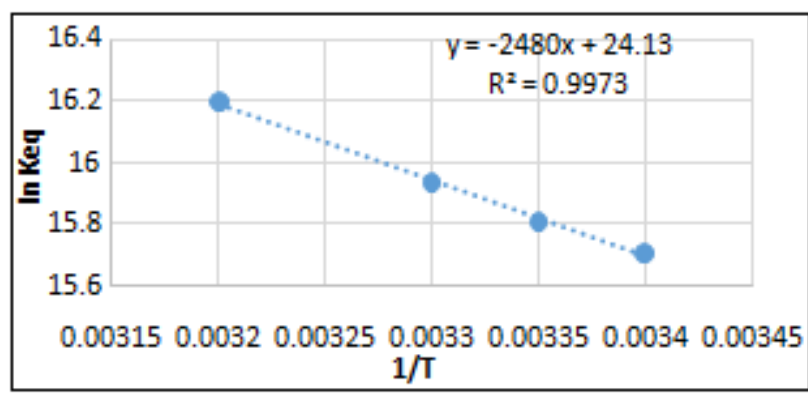

Figure 4: van' t Hoff plot for Ascorbic acid -Nickel in deionized water

The negative values of Gibbs free energy refer to spontaneous interaction between acid and metal ion, in direction of equilibrium and increase with increase in temperature. The positive values of entropy occur because water molecules that arranged around the acid and metal became more random because of hydrophobic interaction. The positive enthalpy and entropy refers to hydrophobic associated and electrostatic interaction [31].

Interaction Kinetics: In order to investigate the interaction kinetic of metal ion with acid the absorbance of complexes was collected with time at a certain wave length $(261 \mathrm{~nm})$, temperature and its stoichiometric ratio. The first order rate equation (7) and the second order rate equation (8) were applied.

$\ln \mathrm{A}=-\mathrm{kt}+\ln \mathrm{A}_{\mathrm{o}} \ldots$ (7) first order equation $(1 / \mathrm{A})-\left(1 / \mathrm{A}_{\mathrm{o}}\right)=\mathrm{Kt} .$. (8) second order equation

$\mathrm{A}=$ absorbance at time $\mathrm{t}$.

$\mathrm{A}_{\mathrm{o}}=$ absorbance at time zero.

$\mathrm{k}=$ rate constant

The complex will be stable in about (50-55 minute) which demonstrated from the constant absorbance. The application of the first and second order of the reaction was shown in Figure5. Table (4) illustrate second order rat constant for the complex of ascorbic acid-nickel

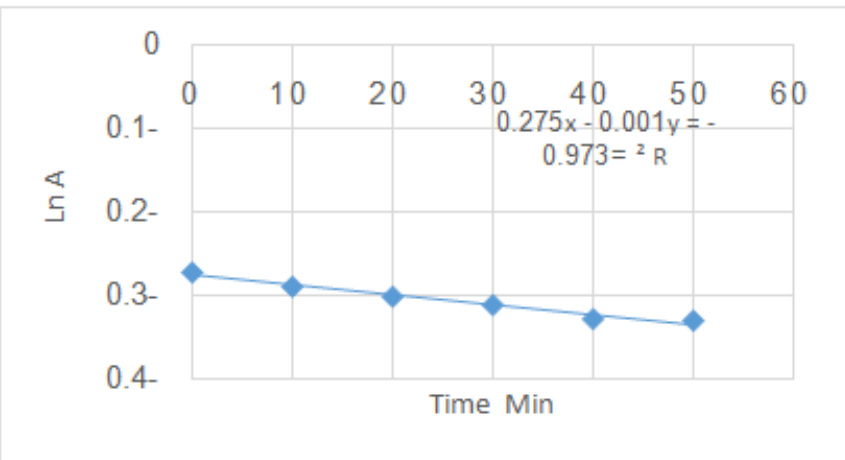

Figure 5 (a): The application of the first order reaction equation for complex ascorbic acid - nickel at $293 \mathrm{~K}$ 


\section{International Journal of Science and Research (IJSR)}

ISSN (Online): 2319-7064

Index Copernicus Value (2016): 79.57 | Impact Factor (2015): 6.391

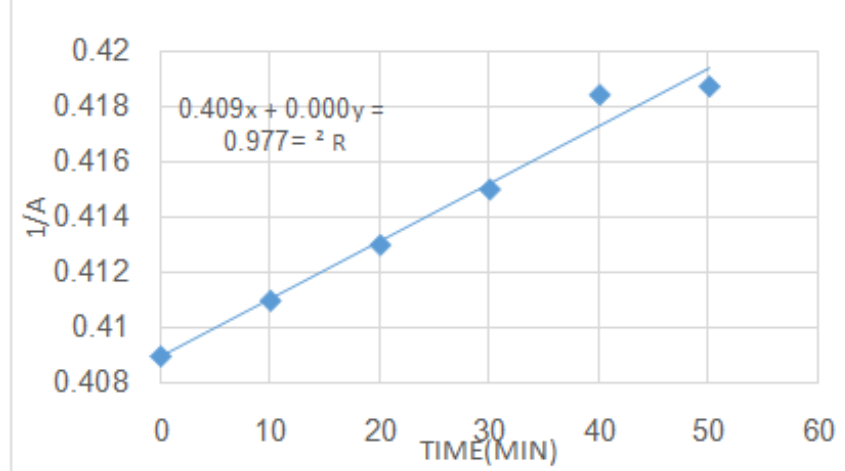

Figure 5 (b): The application of the second order reaction equation for complex ascorbic acid - nickel at $293 \mathrm{~K}$

The interaction between ascorbic acid-nickel is a second order with a rate constant $\mathrm{k}=2 \times 10^{-3} \mathrm{~min}^{-1} \mathrm{M}^{-1}$ )

Table 4: The second order rate constants for ascorbic acid nickel complex

\begin{tabular}{|c|c|c|c|}
\hline $\begin{array}{c}\text { second order } \\
\text { rate constant } \\
\left(\mathrm{min}^{-1} \mathrm{M}^{-1}\right) \text { at } \\
293(\mathrm{~K})\end{array}$ & $\begin{array}{c}\text { second order } \\
\text { rate constant } \\
\left(\mathrm{min}^{-1} \mathrm{M}^{-1}\right) \text { at } \\
298(\mathrm{~K})\end{array}$ & $\begin{array}{c}\text { second order } \\
\text { rate constant } \\
\left(\mathrm{min}^{-1} \mathrm{M}^{-1}\right) \text { at } \\
303(\mathrm{~K})\end{array}$ & $\begin{array}{c}\text { Second order } \\
\text { rate constant } \\
\left(\mathrm{min}^{-1} \mathrm{M}^{-1}\right) \text { at } \\
308(\mathrm{~K})\end{array}$ \\
\hline $2 \times 10^{-3}$ & $3.2 \times 10^{-3}$ & $4.3 \times 10^{-3}$ & $5.1 \times 10^{-3}$ \\
\hline
\end{tabular}

The results from table 4 indicate that the rate constant increasing with increase temperature.

\section{References}

[1] Michel, Davies, John, A. and David, 1991.Vitamin C its chemistry and biochemistry. Thomas Graham House. Cambridge: p-30.

[2] Aguirre, R., May, J.M.2008 "Inflammation in the vascular bed: Importance of vitamin C" Journal of Pharmacology and Therapeutics.,4, pp: 119, 96-103.

[3] Bruick , R.K., McKnight, S.L., 2001. "A conserved family of prolyl-4-hydroxylases that modify" Science, 294, pp: 1337-1340.

[4] Myllyla, R., Majamaa, K., Gunzler, V., Hanauske-Abal, H.M., Kivirikko, K.I.,1984. "Ascorbate is consumed stoichiometric ally in the uncoupled reactions catalyzed by prolyl-4- hydroxylase and lysis hydroxylase" Journal of Biological Chemistry., 259, 5403-5405.

[5] Coassin, M., Tomasi, A., Vannini, V., Ursini, F., 1991. "Enzymatic recycling of oxidized ascorbate in pig heart: one electron vs two-electron pathway" Archives of Biochemistry and Biophysics.,290, pp: 458-462.

[6] Mehlhorn, R.J.,1991. "Ascorbate- and dehydro ascorbic acid-mediated reduction of free radicalsin the human erythrocyte" Journal of Biological Chemistry., 266, pp: 2724-2731.

[7] Biel ski, B.H., Richter, H.W., Chan, P.C., (1975). "Some properties of the ascorbate free radical"Annals of the New York Academy Sciences., 258,pp: 231-237.

[8] Winkler, B.S.,1987. "In vitro oxidation of ascorbic acid and its prevention by GS" Biochemical Biophysical Acta, 925, pp: 258-264.
[9] Chatterjee, I.B., 1970. "Biosynthesis of L-ascorbate in animals" Methods Enzymol., 18, pp:28-34.

[10] Buettner, G.R.,1993. "The pecking order of free radicals and antioxidants lipoid peroxidation, alpha-tocopherol, and ascorbate" Archives of Biochemistry and Biophysics., 300, pp:535-543.

[11]Barnes, M.J.,1975. "Function of ascorbic acid in collagen metabolism" Annals of the New York Academy Sciences., 258, pp: 264-277.

[12] Das k.k., DasS.N., DhundasiS.A.2008.Nickel, its adverse health effects and oxidative stress. Indian journal medical research, 128(4), pp: 25-412.

[13] Nielsen, F.H.,.2013. Biochemistry of the essential ultrace elements. Third Edition. Plenum press, New York, pp293-308.

[14] Huned.Y.J. 2004. Study of the interaction between mono ammonium glycyrrhizin ate and bovine serum albumin. Journal of pharm biomedical analytical, 36, pp:915-919.

[15] Huned.Y.J. 2005. Studies on the interaction between 1hexylcarbamoyl-5-flurouracil and bovine serum albumin. Journal of molecular stricter,738, pp:143-147.

[16]Fahd.D.F.2012.Study of thermodynamic properties of the interaction of an antioxidant with toxic arsenic.M.Sc. Thesis. Department of Chemistry, C0llege of Science.University of Baghdad. Baghdad, Aljadria. Iraq.

[17] Al-Khafaji.N.R.2014.Thermodynamic and kinetic studies for the effectiveness of poly phenols nutritional origin in a protection from metal poisoning.ph. $d$. Thesis. Department of Chemistry, C0llege of Science.University of Baghdad. Baghdad, Aljadria. Iraq.

[18]Al-Rufaie E.M. and Hussain.M.A.2014.Study of interaction between vitamin $\mathrm{c}$ and nickel (II)ion using a polar graphic method. Iraqijournal of science,55(3A). pp:878-885.

[19]Al-jubouriM.A.2015. Thermodynamic and kinetic calculationfor the binding of a heavy metal ion with chelatingtherapy drugs. M.Sc. Thesis.Department of Chemistry, College of Science.University of Baghdad. Baghdad, Aljadria. Iraq.

[20] Job,P.J.;'Formation and stability of inorganic complexes in solution".Ann. chim .;9:113-203;1928.

[21] Maccarthyk., Patrick. D.1986.Novel Approach to Jop's Methods. Journal of Chemical Education, 63(3), pp: 162-167.

[22] Inczedy J. 1976. Analytical applications of complex equilibrium, John Wiley and sons, New York.

[23] Ewing G.W. 1960. Instrumental methods of chemical analysis. McGraw-Hill Inc., New York.

[24] Combaret L. 2000. Molecular Mechanisms in ExerciseInduced Cardio protection. Journal of Physiology, 569, pp: 123-127.

[25] Gibson R.E. and LoeffleO.E..2000. Absorption and Luminescence of Aromatic Molecules. American Chemistry of Society, 62, pp.: 1324.

[26] Stephen L.2004. Cheml Virtual.Second Edition. Burnaby - Vancouver, Canada. 
[27] Guangliang Liu and Yong Cai, (2011), "Complexation of Arsenite with Dissolved Organic Matter: Conditional Distribution Coefficients and Apparent Stability Constants", Chemosphere, vol. 81, no. (7), pp. 890-896.

[28] Atikins P.W.2006. Physical Chemistry.Eighth Edition.Oxford, Oxford University Press. Chicago.

[29] Moron,S.H. and Pruton,C.F. 1982.Principal of Physical Chemistry. Second Edition.The Macmillan Company of India Limited.

[30] Morris S.2003. Chemical kinetics, Ivy publishing House, New Delhi, Sarup and Sons, pp: 2-30.

[31] Karlsson, B. C. and Iian, 2007, The spectrophysics of warfarin: Implications for protein binding.Journal of Physical Chemistry, part B., vol. 111, pp: 10520-10528.

Volume 6 Issue 12, December 2017 www.ijsr.net 